\title{
Factors related to the incorrect use of inhalers by asthma patients*
}

\author{
Fatores relacionados ao uso incorreto dos dispositivos \\ inalatórios em pacientes asmáticos
}

\author{
Paulo de Tarso Roth Dalcin, Denis Maltz Grutcki, Paola Paganella Laporte, \\ Paula Borges de Lima, Samuel Millán Menegotto, Rosemary Petrik Pereira
}

\begin{abstract}
Objective: To evaluate inhaler technique in outpatients with asthma and to determine associations between the correctness of that technique and the level of asthma control. Methods: This was a cross-sectional study involving patients $\geq 14$ years of age with physician-diagnosed asthma. The patients were recruited from the Asthma Outpatient Clinic of the Hospital de Clínicas de Porto Alegre, in the city of Porto Alegre, Brazil. The patients completed two questionnaires (a general questionnaire and an asthma control questionnaire based on the 2011 Global Initiative for Asthma guidelines), demonstrated their inhaler technique, and performed pulmonary function tests. Incorrect inhaler technique was defined as the incorrect execution of at least two of the predefined steps. Results: We included 268 patients. Of those, 81 (30.2\%) showed incorrect inhaler technique, which was associated with poor asthma control $(p=0.002)$. Logistic regression analysis identified the following factors associated with incorrect inhaler technique: being widowed $(\mathrm{OR}=5.01 ; 95 \% \mathrm{Cl}, 1.74-14.41$; $\mathrm{p}=0.003)$; using metered dose inhalers $(\mathrm{OR}=1.58 ; 95 \% \mathrm{Cl}, 1.35-1.85 ; \mathrm{p}<0.001)$; having a monthly family income $<3$ times the minimum wage $(\mathrm{OR}=2.67 ; 95 \% \mathrm{Cl}, 1.35-1.85 ; \mathrm{p}=0.008)$, and having $\geq 2$ comorbidities $(\mathrm{OR}=3.80 ; 95 \% \mathrm{Cl}, 1.03-14.02 ; \mathrm{p}=0.045)$. Conclusions: In the sample studied, incorrect inhaler technique was associated with poor asthma control. Widowhood, use of metered dose inhalers, low socioeconomic level, and the presence of $\geq 2$ comorbidities were associated with incorrect inhaler technique.
\end{abstract}

Keywords: Metered dose inhalers; Dry powder inhalers; Asthma/therapy.

\section{Resumo}

Objetivo: Avaliar a técnica inalatória em pacientes com asma atendidos ambulatorialmente, estabelecendo associações dessa com o grau de controle da doença. Métodos: Estudo transversal envolvendo pacientes com idade $\geq 14$ anos e diagnóstico médico de asma, recrutados no Ambulatório de Asma do Hospital de Clínicas de Porto Alegre, na cidade de Porto Alegre (RS). Os pacientes completaram dois questionários (um geral e um questionário de controle da asma baseado nas diretrizes da Global Initiative for Asthma de 2011). Os pacientes demonstraram a técnica inalatória e realizaram testes de função pulmonar. A técnica inalatória incorreta foi definida como a execução incorreta de pelo menos duas etapas da avaliação. Resultados: Foram incluídos 268 pacientes. Desses, $81(30,2 \%)$ apresentaram técnica inalatória incorreta, que foi associada com falta de controle da asma $(p=0,002)$. A regressão logística identificou os seguintes fatores associados com a técnica inalatória incorreta: ser viúvo $(O R=5,01 ; 1 C 95 \%, 1,74-14,41 ; p=0,003)$; utilizar inalador pressurizado $(O R=1,58$; 1C95\%, 1,35-1,85; $\mathrm{p}<$ 0,001); ter renda familiar mensal < 3 salários mínimos $(0 R=2,67 ; 1$ C95\%, 1,35-1,85; $p$ $=0,008)$; e ter $\geq 2$ comorbidades ( $O R=3,80 ; 1 C 95 \%, 1,03-14,02 ; p=0,045)$. Conclusões: Na amostra estudada, a técnica inalatória incorreta se associou com a falta de controle da asma. Viuvez, uso de inalador pressurizado, baixo nível socioeconômico e presença de $\geq 2$ comorbidades se associaram à técnica inalatória incorreta.

Descritores: Inaladores dosimetrados; Inaladores de pó seco; Asma/terapia.

*Study carried out under the auspices of the Graduate Program in Pulmonology, Federal University of Rio Grande do Sul School of Medicine; and in the Department of Pulmonology, Porto Alegre Hospital de Clínicas, Porto Alegre, Brazil.

Correspondence to: Paulo de Tarso Roth Dalcin. Rua Honório Silveira Dias, 1529/901, São João, CEP: 90540-070, Porto Alegre, RS, Brasil.

Tel. 5551 3330-0521. E-mail: pdalcin@terra.com.br

Financial support: This study received financial support from the Fundo de Incentivo à Pesquisa do Hospital de Clínicas de Porto Alegre (FIPE-HCPA, Research Incentive Fund of the Porto Alegre Hospital de Clínicas). Denis Maltz Grutcki was the recipient of an extension grant from the Federal University of Rio Grande do Sul Dean's Office for Extension Grants.

Submitted: 8 May 2013. Accepted, after review: 28 October 2013. 


\section{Introduction}

Asthma is one of the most common chronic conditions. Although the results of clinical findings have shown that asthma control can be achieved in most patients, epidemiological evidence suggests that there is a significant gap between treatment goals and the actual level of control achieved with treatment in the general population. ${ }^{(1)}$ Therefore, there remains the challenge of identifying the factors that are related to poor asthma control and of developing strategies to ensure that asthma control is achieved and maintained. ${ }^{(2)}$

Inhaled drugs are the primary treatment for asthma. ${ }^{(3)}$ Incorrect handling of inhalers and inappropriate inhaler technique result in low bronchial deposition of the drug and can contribute to poor asthma control. ${ }^{(4)}$ Understanding the frequency and type of inhaler technique errors, as well as their associations with the level of asthma control, may allow the development of educational strategies to help reduce the morbidity of the disease. ${ }^{(5)}$

The objective of the present article was to assess inhaler technique in outpatients with asthma and to determine associations between the correctness of that technique and the level of asthma control.

\section{Methods}

This was a cross-sectional study. The study protocol was approved by the Research Ethics Committee of the Hospital de Clínicas de Porto Alegre (HCPA, Porto Alegre Hospital de Clínicas), located in the city of Porto Alegre, Brazil. Written informed consent was obtained from all patients or their legal guardians, in the case of those under 18 years of age. The study population consisted of patients treated at the HCPA outpatient clinics specializing in asthma. Individuals aged 18 years or older who had a previous diagnosis of asthma were sequentially recruited. A physician who was a member of the research team confirmed the diagnosis on the basis of the following criteria ${ }^{(6)}$ : symptoms consistent with asthma, accompanied by reversible airflow obstruction (an increase in $\mathrm{FEV}_{1} \geq 12 \%$ and $\geq 200 \mathrm{~mL}$ after administration of an inhaled short-acting $\beta_{2}$ agonist) or by hyperresponsiveness to a bronchial challenge agent. Patients should have made two prior visits to one of the outpatient clinics mentioned above, and the pharmacological treatment regimen should have already been adjusted to the level of asthma severity. Patients should be receiving inhaled corticosteroids alone or in combination with long-acting $\beta_{2}$ agonists.

The exclusion criteria were declining to participate in the study, having another chronic lung disease (emphysema, chronic bronchitis, or bronchiectasis), not using inhaled drugs, and failing to complete all of the evaluations required by the study protocol.

The questionnaire used to interview patients included a checklist for assessing patient handling of the device used to inhale the corticosteroid. Prior to the study outset, the principal investigator trained all members of the research team on the correct use of each device and on how to score each stage of the evaluation process. Patients were asked to demonstrate their inhaler technique, using placebo. For metered dose inhalers, patients were assessed for their performance of the following steps: a) shaking the inhaler before using it; b) exhaling normally before using the inhaler; $c$ ) holding the inhaler at an appropriate distance (3-5 cm) from the lips if a spacer is not used or, if a spacer is used, placing the inhaler in the mouth and creating an adequate seal with the lips; d) inhaling slowly and deeply after squeezing the inhaler; and e) performing a breath-hold of at least 10 seconds (after inhalation). For dry powder inhalers, patients were assessed for their performance of the following steps: a) exhaling normally before using the inhaler; b) placing the inhaler in the mouth and creating an adequate seal with the lips; c) inhaling as forcefully and deeply as possible; and d) performing a breathhold of at least 10 seconds (after inhalation).

Asthma severity was categorized on the basis of the daily medication regimen in use, as proposed in the Global Initiative for Asthma (GINA) guidelines. ${ }^{(3)}$

The level of asthma control was assessed in accordance with the classification proposed in the 2011 GINA guidelines (Chart 1). ${ }^{(3)}$

Pulmonary function was assessed with a computerized spirometer (MasterScreen v4.31; Jaeger, Würzburg, Germany). We recorded FVC, $\mathrm{FEV}_{1}$, and the $\mathrm{FEV}_{1} / \mathrm{FVC}$ ratio. All parameters are expressed as a percentage of the predicted value for age, gender, and height. ${ }^{(7)}$

Measurements of PEF were performed with a portable peak flow monitor (Vitalograph; Boehringer Ingelheim, Ingelheim am Rhein, 
Chart 1 - Criteria for assessing the level of asthma control.

\begin{tabular}{|c|c|c|}
\hline \multicolumn{3}{|c|}{ Level of asthma control } \\
\hline Controlled & Partially controlled & Uncontrolled \\
\hline (presence of all criteria) & $\begin{array}{c}\text { (presence of any criteria in any given } \\
\text { week) }\end{array}$ & (presence of any criteria) \\
\hline $\begin{array}{ll}\text { - } & \text { Daytime symptoms twice a } \\
\text { - } & \text { Neek or less } \\
\text { - } & \text { No nocturnitation of activities } \\
\text { awakenings } \\
\text { - } \quad \begin{array}{l}\text { Rescue medication twice a } \\
\text { week or less }\end{array} \\
\text { - }\end{array}$ & $\begin{array}{l}\text { - } \\
\text { Daytime symptoms twice a } \\
\text { week or less } \\
\text { - } \quad \text { Any limitation of activities } \\
\text { - } \quad \text { any nocturnal symptom/ } \\
\text { Rescue medication more than } \\
\text { twice a week } \\
\text { Pulmonary function < 80\% of } \\
\text { the predicted value or of the } \\
\text { personal best value, if known }\end{array}$ & $\begin{array}{l}\text { - } 3 \text { or more criteria of partially } \\
\text { controlled asthma in any given } \\
\text { week } \\
\text { Exacerbation requiring the use } \\
\text { of oral corticosteroids in any } \\
\text { given week } \\
\text { Hospitalization/emergency } \\
\text { room admission for asthma in } \\
\text { the last } 12 \text { months }\end{array}$ \\
\hline
\end{tabular}

${ }^{a}$ In accordance with the Global Initiative for Asthma. ${ }^{(4)}$

Germany). The results are expressed as a percentage of the predicted value for age, gender, and height. ${ }^{(8)}$

For the statistical analysis, we used the Statistical Package for the Social Sciences, version 18.0 (SPSS Inc., Chicago, IL, USA). Data are expressed as number (percentage) of cases, mean $\pm \mathrm{SD}$, or median (interquartile range).

For each patient, the number of inhaler technique errors was recorded. In the present sample, the association between the number of errors (dichotomized into one or more errors and two or more errors) and the level of asthma control (controlled, partially controlled, and uncontrolled) was analyzed by the chi-square test. We found that the cut-off point of one or more errors was not significantly associated with the level of asthma control ( $p=0.07)$, whereas the cut-off point of two or more errors was significantly associated with the level of asthma control ( $p=$ 0.002). Therefore, correct inhaler technique was defined as making less than two inhaler technique errors, whereas incorrect inhaler technique was defined as making two or more errors.

Patients with correct inhaler technique and patients with incorrect inhaler technique were compared for categorical variables using the chi-square test with adjusted standardized residuals and, when necessary, Yates' correction or Fisher's exact test. Continuous variables were compared by the independent sample t-test or the MannWhitney $\mathrm{U}$ test.

A binary logistic regression model (enter method) was used to identify characteristics predictive of incorrect inhaler technique. Variables with a significance level less than 0.1 in univariate analysis, adjusted for gender and age, were included in a logistic regression model.

All statistical tests were two-tailed. The level of significance was set at 5\%.

\section{Results}

A total of 334 eligible patients were examined. Thirty patients declined to participate, 27 patients were excluded because they had another chronic lung disease, 7 patients were excluded because they did not use the prescribed inhaled drug, and 2 patients were excluded because they failed to complete all of the evaluations required by the study protocol. Therefore, 268 individuals completed the study. Of those, 187 patients showed correct inhaler technique and 81 (30.2\%) showed incorrect technique.

Table 1 shows the general characteristics of the study patients. One hundred and ninetynine patients $(74.3 \%)$ were female, and 223 (83.2\%) were White. The mean age was 50.9 \pm 16.5 years. Most patients $(60.1 \%)$ had had 8 years of schooling or less, and $186(69.4 \%)$ had a monthly family income of less than three times the national minimum wage. Asthma severity was classified as mild persistent in $37(13.8 \%)$ of the patients, as moderate persistent in 89 (33.2\%), and as severe persistent in 142 (53.0\%). Asthma was classified as controlled in 47 (17.5\%) of the patients, as partially controlled in $74(27.6 \%)$, and as uncontrolled in 147 (54.9\%).

Table 2 shows the comparison between groups formed on the basis of inhaler technique assessment. Statistically significant differences 
Table 1 - General characteristics of the 268 study patients. ${ }^{a}$

\begin{tabular}{|c|c|}
\hline Variable & Result \\
\hline \multicolumn{2}{|l|}{ Gender } \\
\hline Female & 199 (74.3) \\
\hline Male & $69(25.7)$ \\
\hline Age, years & $50.9 \pm 16.5$ \\
\hline \multicolumn{2}{|l|}{ Ethnicity } \\
\hline White & $223(83.2)$ \\
\hline Non-White & $45(16.8)$ \\
\hline \multicolumn{2}{|l|}{ Marital status } \\
\hline Married/spouse & $142(53.0)$ \\
\hline Divorced/separated & $34(12.7)$ \\
\hline Widowed & $26(9.7)$ \\
\hline Single & $66(24.6)$ \\
\hline \multicolumn{2}{|l|}{ Level of education } \\
\hline$<9$ years of schooling & $161(60.1)$ \\
\hline$=9$ years of schooling & $88(32.8)$ \\
\hline College & $19(7.1)$ \\
\hline \multicolumn{2}{|c|}{$\begin{array}{l}\text { Monthly family income, number } \\
\text { of times the national minimum } \\
\text { wage }\end{array}$} \\
\hline$<3$ & $186(69.4)$ \\
\hline $3-10$ & $79(29.5)$ \\
\hline$>10$ & $3(1.1)$ \\
\hline \multicolumn{2}{|l|}{ Smoking status } \\
\hline Never smoker & $162(60.4)$ \\
\hline Former smoker & $97(36.2)$ \\
\hline Smoker & $9(3.4)$ \\
\hline \multicolumn{2}{|l|}{ Comorbidities } \\
\hline 0 & $160(59.7)$ \\
\hline 1 & $94(35.1)$ \\
\hline$\geq 2$ & $14(5.2)$ \\
\hline \multicolumn{2}{|c|}{ Level of asthma severity (GINA) } \\
\hline Mild persistent & $37(13.8)$ \\
\hline Moderate persistent & $89(33.2)$ \\
\hline Severe persistent & $142(53.0)$ \\
\hline \multicolumn{2}{|c|}{ Level of asthma control (GINA) } \\
\hline Controlled & $47(17.5)$ \\
\hline Partially controlled & $74(27.6)$ \\
\hline Uncontrolled & 147 (54.9) \\
\hline FVC, \% of predicted & $83.7 \pm 21.0$ \\
\hline $\mathrm{FEV}_{1}, \%$ of predicted & $68.8 \pm 22.9$ \\
\hline $\mathrm{FVC} \mathrm{FEV}_{1}, \%$ of predicted & $80.9 \pm 14.3$ \\
\hline
\end{tabular}

GINA: Global Initiative for Asthma. ${ }^{\text {a Values expressed as } n}$ (\%), except where otherwise indicated. ${ }^{b}$ Values expressed as mean $\pm \mathrm{SD}$.

were found for the following variables: marital status ( $p=0.002)$, the proportion of widowed patients being higher among those with incorrect inhaler technique; level of education ( $p=0.023)$, the proportion of patients who had had 8 years of schooling or less being higher among those with incorrect inhaler technique; monthly family income ( $p=0.016)$, the proportion of patients with an income of less than three times the national minimum wage being higher among those with incorrect inhaler technique; and level of asthma control $(p=0.007)$, the proportion of patients with uncontrolled asthma being higher among those with incorrect inhaler technique.

Table 3 shows that there was a statistically significant difference in type of inhaler used ( $p$ $<0.001$ ) between the two groups formed on the basis of inhaler technique assessment, the proportion of patients with correct technique being higher among those using dry powder inhalers than among those using metered dose inhalers. In addition, the proportion of patients with correct inhaler technique differed significantly among each specific type of inhaler used ( $p<$ 0.001), the proportion of patients with correct inhaler technique being higher among those using Aerolizer ${ }^{\circledast}$ or Turbuhaler ${ }^{\circledast}$. In contrast, we found a higher proportion of patients with incorrect technique among those using metered dose inhalers without spacers.

Table 4 shows the logistic regression for factors related to incorrect inhaler technique. The following variables were independently associated with incorrect inhaler technique: being widowed $(\mathrm{OR}=5.01 ; 95 \% \mathrm{Cl}, 1.74-14.41$; $\mathrm{p}=0.003)$; using metered dose inhalers $(\mathrm{OR}=$ $1.58 ; 95 \% \mathrm{Cl}, 1.35-1.85 ; \mathrm{p}<0.001)$; having a monthly family income of less than three times the national minimum wage $(\mathrm{OR}=2.67 ; 95 \%$ $\mathrm{Cl}, 1.35-1.85 ; \mathrm{p}=0.008)$, and having two or more comorbidities $(\mathrm{OR}=3.80 ; 95 \% \mathrm{Cl}, 1.03$ $14.02 ; p=0.045)$.

\section{Discussion}

The present study showed that the number of inhaler technique errors has a significant impact on the level of asthma control. The variables that were associated with incorrect inhaler technique were being widowed, using metered dose inhalers, having a monthly family income of less than three times the national minimum wage, and having two or more comorbidities.

Incorrect inhaler technique in asthma treatment can substantially reduce lung deposition of the drug, undermining the effectiveness of asthma treatment. In the present study, incorrect inhaler technique (i.e., making 2 or more errors) was 
Table 2 - Comparison between groups formed on the basis of inhaler technique assessment. ${ }^{\mathrm{a}}$

\begin{tabular}{|c|c|c|c|}
\hline \multirow[t]{3}{*}{ Variable } & \multicolumn{2}{|c|}{ Groups $^{b}$} & \multirow[t]{3}{*}{$\mathrm{p}$} \\
\hline & Correct technique & Incorrect technique & \\
\hline & $(\mathrm{n}=187)$ & $(n=81)$ & \\
\hline Gender & & & 0.474 \\
\hline Female & $136(72.7)$ & $63(77.8)$ & \\
\hline Male & $51(27.3)$ & $18(22.2)$ & \\
\hline Age, years ${ }^{c}$ & $50.4 \pm 16.5$ & $52.7 \pm 16.8$ & 0.296 \\
\hline Ethnicity & & & 0.971 \\
\hline White & $155(82.9)$ & $68(84.0)$ & \\
\hline Non-White & $32(17.1)$ & $13(16.0)$ & \\
\hline Age at diagnosis of asthma, years ${ }^{d}$ & $26.0(71.0)$ & $24.0(40.0)$ & 0.966 \\
\hline Marital status & & & 0.002 \\
\hline Married/spouse & $106(56.7)$ & $36(44.4)$ & \\
\hline Divorced/separated & $22(11.8)$ & $12(14.8)$ & \\
\hline Widowed & $10(5.3)^{*}$ & $16(19.8)^{*}$ & \\
\hline Single & $49(26.2)$ & $17(21.0)$ & \\
\hline Level of education & & & 0.023 \\
\hline$<9$ years of schooling & $105(56.1)^{*}$ & $56(69.1)^{*}$ & \\
\hline$=9$ years of schooling & $64(34.2)$ & $24(29.6)$ & \\
\hline College & $18(9.6)^{*}$ & $1(1.2)^{*}$ & \\
\hline $\begin{array}{l}\text { Monthly family income, number of } \\
\text { times the national minimum wage }\end{array}$ & & & 0.016 \\
\hline$<3$ & $120(64.2)^{*}$ & $66(81.5)^{*}$ & \\
\hline $3-10$ & $65(34.8)^{*}$ & $14(17.3)^{*}$ & \\
\hline$>10$ & $2(1.1)$ & $1(1.2)$ & \\
\hline Smoking status & & & 0.226 \\
\hline Never smoker & $119(63.6)$ & $43(53.1)$ & \\
\hline Former smoker & $63(33.7)$ & $34(42.0)$ & \\
\hline Smoker & $5(2.7)$ & $4(4.9)$ & \\
\hline Comorbidities & & & 0.055 \\
\hline 0 & $117(62.6)$ & $43(53.1)$ & \\
\hline 1 & $64(34.2)$ & $30(37.0)$ & \\
\hline$\geq 2$ & $6(3.2)$ & $8(9.9)$ & \\
\hline Level of asthma severity (GINA) & & & 0.094 \\
\hline Mild intermittent or persistent & $31(16.6)$ & $6(7.4)$ & \\
\hline Moderate persistent & $63(33.7)$ & $26(32.1)$ & \\
\hline Severe persistent & $93(49.7)$ & $49(60.5)$ & \\
\hline Level of asthma control (GINA) & & & 0.007 \\
\hline Controlled & $39(20.9)^{*}$ & $8(9.9)^{*}$ & \\
\hline Partially controlled & $57(30.5)$ & $17(21.0)$ & \\
\hline Uncontrolled & $91(48.7)^{*}$ & $56(69.1)^{*}$ & \\
\hline FVC, $\%$ of predicted ${ }^{c}$ & $83.5 \pm 20.8$ & $84.5 \pm 22.0$ & 0.748 \\
\hline $\mathrm{FEV}_{1}, \%$ of predicted ${ }^{\mathrm{c}}$ & $68.0 \pm 23.7$ & $71.2 \pm 21.5$ & 0.337 \\
\hline FVC/FEV $_{1}, \%$ of predicted ${ }^{c}$ & $65.8 \pm 13.2$ & $66.8 \pm 11.1$ & 0.605 \\
\hline PEF, $\%$ of predicted ${ }^{c}$ & $64.9 \pm 22.9$ & $61.3 \pm 20.2$ & 0.232 \\
\hline
\end{tabular}

GINA: Global Initiative for Asthma. ${ }^{a}$ Values expressed as $n(\%)$, except where otherwise indicated. ${ }^{\text {b}}$ Correct technique was defined as making $<2$ inhaler technique errors; incorrect technique was defined as making $\geq 2$ inhaler technique errors. 'Values expressed as mean \pm SD. ${ }^{d}$ Value expressed as median (interquartile range). *Statistically significant adjusted standardized residuals $(<-1.96$ or $>1.96)$. The independent sample t-test was used for variables with normal distribution; the MannWhitney $\mathrm{U}$ test was used for variables without normal distribution; and the chi-square test was used for categorical variables.

associated with poor asthma control. It is of note that a previous study, ${ }^{(9)}$ in which incorrect inhaler technique was defined as making one or more errors, found no association between the correctness of inhaler technique and the level of asthma control. 
Table 3 - Inhaler technique and type of inhaler used. ${ }^{\text {a }}$

\begin{tabular}{lccc}
\hline \multirow{2}{*}{ Variable } & \multicolumn{2}{c}{ Groups $^{\mathrm{b}}$} & $\mathrm{p}^{*}$ \\
\cline { 2 - 3 } & Correct technique & Incorrect technique & \\
\cline { 2 - 3 } Type of inhaler & $61(32.6)^{*}$ & $59(72.8)^{*}$ & $<0.001$ \\
Metered dose inhaler & $89(47.6)^{*}$ & $18(22.2)^{*}$ & \\
Aerolizer $^{\infty}$ & $20(10.7)^{*}$ & $1(1.2)^{*}$ & \\
Turbuhaler $^{\infty}$ & $15(8.0)$ & $3(3.7)$ & \\
Diskus $^{\infty}$ & $2(1.1)$ & $0(0.0)$ & \\
Pulvinal $^{\infty}$ & & & \\
\hline
\end{tabular}

${ }^{\text {a }}$ Values expressed as $\mathrm{n}(\%)$. ${ }^{\mathrm{b}}$ Correct technique was defined as making $<2$ inhaler technique errors; incorrect technique was defined as making $\geq 2$ inhaler technique errors. *Statistically significant adjusted standardized residuals $(<-1.96$ or $>1.96)$. ${ }^{*}$ Chi-square test.

Table 4 - Binary logistic regression for factors related to incorrect inhaler technique.

\begin{tabular}{lccccc}
\hline \multicolumn{1}{c}{ Variable } & $\mathrm{b}$ & Wald & $\mathrm{p}$ & $\mathrm{OR}$ & $95 \% \mathrm{Cl}$ \\
\hline Age & 0.003 & 0.09 & 0.770 & 1.00 & $0.98-1.02$ \\
Male gender & -0.54 & 2.12 & 0.145 & 0.58 & $0.28-1.20$ \\
Being widowed & -1.61 & 8.93 & 0.003 & 5.01 & $1.74-14.41$ \\
Using metered dose inhalers & 0.45 & 31.75 & $<0.001$ & 1.58 & $1.35-1.85$ \\
Having had < 9 years of schooling & 0.41 & 1.55 & 0.213 & 1.51 & $0.79-2.90$ \\
Having a monthly family income $<3$ & 0.98 & 7.03 & 0.008 & 2.67 & $1.35-1.85$ \\
times the national minimum wage & & & & & \\
Having $\geq 2$ comorbidities & 1.34 & 4.02 & 0.045 & 3.80 & $1.03-14.02$ \\
Constant & -4.14 & 10.33 & 0.001 & 0.016 & - \\
\hline
\end{tabular}

Studies have suggested that 32\% to $96 \%$ of asthma patients make errors when using their inhalers, and that, in $28 \%$ to $68 \%$ of cases, those errors are important to the point of undermining the effects of treatment. ${ }^{(10,11)}$ In the present study, $30.2 \%$ of the patients made two or more inhaler technique errors, and this cut-off point was associated with asthma control. In contrast to these findings, in a study conducted in Brazil, Coelho et al. ${ }^{(12)}$ evaluated handling of inhaler devices by 467 patients with severe asthma who were followed at a center in the state of Bahia and observed that most patients showed appropriate inhaler technique, a finding that was attributed to the intense educational intervention that those patients received at a referral center.

Performing the inhaler technique correctly depends on the type of inhaler. A systematic review $^{(11)}$ has shown that patients using dry powder inhalers had lower rates of inhaler technique errors than did those using metered dose inhalers. The present study adds to the evidence that the proportion of patients with inappropriate inhaler technique is higher among patients using metered dose inhalers than among those using dry powder inhalers. This difference is even greater when patients using metered dose inhalers without spacers are considered. Metered dose inhalers are more difficult to use, because they require greater motor coordination. The use of a spacer reduces the need for greater motor coordination, but, despite that, metered dose inhalers remain more difficult to use than dry powder inhalers, which leads to a higher proportion of inhaler technique errors. ${ }^{(11,13)}$ However, one factor to be considered in the present study is that the number of inhaler technique steps assessed was greater for metered dose inhaler use (five steps) than for dry powder inhaler use (four steps). This may indicate a bias in the present study, with the requirement for classifying the technique as correct being more stringent for individuals using metered dose inhalers. However, this is more likely to represent the greater complexity of performing the inhaler technique with metered dose inhalers than with dry powder inhalers.

In the present study, a higher proportion of patients with inappropriate technique were found among those with a monthly family income of less than three times the national minimum wage. A previous study has shown that, to ensure appropriate treatment and reduce asthma 
morbidity, it is necessary that socioeconomically disadvantaged patients receive a more intense educational approach..$^{(14)}$

The level of support provided by family members or caregivers can also contribute to the appropriate performance of the inhaler technique. (15) In our study, we found that inappropriate inhaler technique was more common among widowed patients. Widowhood can contribute to a varying degree of social isolation and loneliness that can negatively impact the treatment of chronic diseases. ${ }^{(16)}$

The physical or mental impairment induced by the presence of other diseases can negatively impact the use of inhalers. Conditions such as tremors, vision impairment, hearing impairment, arthritis, mood disorders, and cognitive disorders can impair learning of the inhaler technique or its appropriate performance. ${ }^{(14)}$ In the present study, the presence of two or more comorbidities was associated with inappropriate inhaler technique. However, we did not specifically address which diseases were more prevalent in this association.

Since the present study found a large proportion of patients with uncontrolled asthma (69.1\%), it is important to highlight the fact that a previous study ${ }^{(9)}$ conducted in Brazil showed that the level of asthma control was associated with asthma severity, access to medication, and appropriate use of inhaled corticosteroids. Therefore, since our study was carried out at a public tertiary care center, it is natural that cases that are more difficult to control will be referred there for treatment and that, in contrast, controlled asthma cases will be sent back for treatment at public primary care clinics.

The present study has some limitations to consider. First, it was a cross-sectional study and, therefore, it does not allow the establishment of a temporal sequence between the quality of the patients' performance of the inhaler technique and their level of asthma control. Second, the study was carried out at a single center that provides care within the public health system. Consequently, the study population consisted of individuals who had a low monthly family income and a low educational level, and this may limit the generalization of results.

The clinical implications of this study lie primarily in the demonstration of the fact that two or more inhaler technique errors affect the level of asthma control, with $30.2 \%$ of the patients studied showing inappropriate inhaler technique on the basis of this definition. In addition, our findings indicate that target group patients such as widowed patients, patients using metered dose inhalers, patients with a monthly family income of less than three times the national minimum wage, and patients with two or more comorbidities require special attention in terms of inhaler technique education. Therefore, it is important that educational strategies for asthma patients be developed to improve their performance of the inhaler technique and increase their level of asthma control.

\section{References}

1. Bateman ED, Boushey HA, Bousquet J, Busse WW, Clark TJ, Pauwels RA, et al. Can guideline-defined asthma control be achieved? The Gaining Optimal Asthma Control study. Am J Respir Crit Care Med. 2004;170(8):836-44. http:// dx.doi.org/10.1164/rccm.200401-0330C PMid:15256389

2. Cazzoletti L, Marcon A, Janson C, Corsico A, Jarvis D, Pin 1, et al. Asthma control in Europe: a real-world evaluation based on an international population-based study. J Allergy Clin Immunol. 2007;120(6):1360-7. http:// dx.doi.org/10.1016/j.jaci.2007.09.019 PMid:17981317

3. Global Initiative for Asthma. Global strategy for asthma management and prevention. Bethesda: National Institutes of Health; 2011.

4. Molimard M, Raherison C, Lignot S, Depont F, Abouelfath A, Moore N, et al. Assessment of handling of inhaler devices in real life: an observational study in 3811 patients in primary care. J Aerosol Med. 2003;16(3):249-54. http:// dx.doi.org/10.1089/089426803769017613 PMid:14572322

5. Roy A, Battle K, Lurslurchachai L, Halm EA, Wisnivesky JP. Inhaler device, administration technique, and adherence to inhaled corticosteroids in patients with asthma. Prim Care Respir J. 2011;20(2):148-54. http://dx.doi.org/10.4104/ pcrj.2011.00022 PMid:21437565

6. IV Brazilian Guidelines for the management of asthma [Article in Portuguese]. J Bras Pneumol. 2006;32 Suppl 7:S447-74. PMid:17420905

7. Pereira CA, Barreto SP, Simões JG, Pereira FW, Gerstler JG, Nakatani J. Valores de referência para espirometria em uma amostra da população brasileira adulta. J Pneumol. 1992;18(1):10-22.

8. Gregg l, Nunn AJ. Peak expiratory flow in normal subjects. Br Med J. 1973;3(5874):282-4. http://dx.doi.org/10.1136/ bmj.3.5874.282

9. Dalcin PT, Menegotto DM, Zanonato A, Franciscatto L, Soliman F, Figueiredo M, et al. Factors associated with uncontrolled asthma in Porto Alegre, Brazil. Braz J Med Biol Res. 2009;42(11):1097-103. http://dx.doi. org/10.1590/S0100-879X2009005000035 PMid:19820883

10. Chrystyn H, Price D. Not all asthma inhalers are the same: factors to consider when prescribing an inhaler. Prim Care Respir J. 2009;18(4):243-9. http://dx.doi. org/10.4104/pcrj.2009.00029 PMid:19513494

11. Cochrane MG, Bala MV, Downs KE, Mauskopf J, Ben-Joseph RH. Inhaled corticosteroids for asthma therapy: patient compliance, devices, and inhalation 
technique. Chest. 2000;117(2):542-50. http://dx.doi. org/10.1378/chest.117.2.542 PMid:10669701

12. Coelho AC, Souza-Machado A, Leite M, Almeida P, Castro L, Cruz CS, et al. Use of inhaler devices and asthma control in severe asthma patients at a referral center in the city of Salvador, Brazil. J Bras Pneumol. 2011;37(6):720-8. PMid:22241028

13. Khassawneh BY, Al-Ali MK, Alzoubi KH, Batarseh MZ, Al-Safi SA, Sharara AM, et al. Handling of inhaler devices in actual pulmonary practice: metered-dose inhaler versus dry powder inhalers. Respir Care. 2008;53(3):324-8. PMid:18291048

14. Yawn BP, Colice GL, Hodder R. Practical aspects of inhaler use in the management of chronic obstructive pulmonary disease in the primary care setting. Int $\mathrm{J}$ Chron Obstruct Pulmon Dis. 2012;7:495-502. http:// dx.doi.org/10.2147/COPD.S32674 PMid:22888221 PMCid:PMC3413176

15. de Oliveira MA, Faresin SM, Bruno VF, de Bittencourt AR, Fernandes AL. Evaluation of an educational programme for socially deprived asthma patients. Eur Respir J. 1999;14(4):908-14. http://dx.doi.org/10.1034/j.13993003.1999.14d30.x PMid:10573241

16. Aartsen MJ, Van Tilburg T, Smits CH, Comijs HC, Knipscheer KC. Does widowhood affect memory performance of older persons? Psychol Med. 2005;35(2):217-26. http:// dx.doi.org/10.1017/S0033291704002831 PMid:15841679

\section{About the authors}

\section{Paulo de Tarso Roth Dalcin}

Associate Professor. Graduate Program in Pulmonology. Federal University of Rio Grande do Sul School of Medicine; and Pulmonologist. Porto Alegre Hospital de Clínicas, Porto Alegre, Brazil.

\section{Denis Maltz Grutcki}

Medical Student. Federal University of Rio Grande do Sul School of Medicine, Porto Alegre, Brazil.

\section{Paola Paganella Laporte}

Medical Student. Federal University of Rio Grande do Sul School of Medicine, Porto Alegre, Brazil.

\section{Paula Borges de Lima}

Medical Student. Federal University of Rio Grande do Sul School of Medicine, Porto Alegre, Brazil.

\section{Samuel Millán Menegotto}

Medical Student. Federal University of Rio Grande do Sul School of Medicine, Porto Alegre, Brazil.

\section{Rosemary Petrik Pereira}

Adjunct Professor. Federal University of Rio Grande do Sul School of Medicine, Porto Alegre, Brazil. 